Article

\title{
Eco-Friendly Formulated Zinc Oxide Nanoparticles: Induction of Cell Cycle Arrest and Apoptosis in the MCF-7 Cancer Cell Line
}

Amin Boroumand Moghaddam ${ }^{1,2}$, Mona Moniri ${ }^{1,2}$, Susan Azizi ${ }^{1, *}$ (D), Raha Abdul Rahim ${ }^{3}$, Arbakariya Bin Ariff ${ }^{1,4}$, Mohammad Navaderi ${ }^{5}$ and Rosfarizan Mohamad $1,6, *$

1 Department of Bioprocess Technology, Faculty of Biotechnology and Biomolecular Sciences, Universiti Putra Malaysia, 43400 UPM Serdang, Selangor, Malaysia; amin.broomandm@yahoo.com (A.B.M.); mona_moniri6@yahoo.com (M.M.); arbarif@upm.edu.my (A.B.A.)

2 Young Research and Elite Club, Sabzevar Branch, Islamic Azad University, Sabzevar, Iran

3 Department of Cell and Molecular Biology, Faculty of Biotechnology and Biomolecular Sciences, Universiti Putra Malaysia, 43400 UPM Serdang, Selangor, Malaysia; raha@upm.edu.my

4 Bioprocessing and Biomanufacturing Research Centre, Faculty of Biotechnology and Biomolecular Sciences, Universiti Putra Malaysia, 43400 UPM Serdang, Selangor, Malaysia

5 Young Research and Elite Club, Parand Branch, Islamic Azad University, Parand, Iran; navaderimohammad@yahoo.com

6 Institute of Tropical Forestry and Forest Products, Universiti Putra Malaysia, 43400 UPM Serdang, Selangor, Malaysia

* $\quad$ Correspondence: azisusan@gmail.com (S.A.); farizan@upm.edu.my (R.M.); Tel.: +60-13-3263-6029 (S.A.); +60-13-263-6029 (R.M.)

Received: 14 August 2017; Accepted: 6 October 2017; Published: 20 October 2017

\begin{abstract}
Green products have strong potential in the discovery and development of unique drugs. Zinc oxide nanoparticles (ZnO NPs) have been observed to have powerful cytotoxicity against cells that cause breast cancer. The present study aims to examine the cell cycle profile, status of cell death, and pathways of apoptosis in breast cancer cells (MCF-7) treated with biosynthesized ZnO NPs. The anti-proliferative activity of ZnO NPs was determined using MTT assay. Cell cycle analysis and the mode of cell death were evaluated using a flow cytometry instrument. Quantitative real-time-PCR (qRT-PCR) was employed to investigate the expression of apoptosis in MCF-7 cells. ZnO NPs were cytotoxic to the MCF-7 cells in a dose-dependent manner. The 50\% growth inhibition concentration $\left(\mathrm{IC}_{50}\right)$ of $\mathrm{ZnO}$ NPs at $24 \mathrm{~h}$ was $121 \mu \mathrm{g} / \mathrm{mL}$. Cell cycle analysis revealed that $\mathrm{ZnO} \mathrm{NPs}$ induced sub- $\mathrm{G}_{1}$ phase (apoptosis), with values of $1.87 \%$ at $0 \mu \mathrm{g} / \mathrm{mL}$ (control), $71.49 \%$ at $\mathrm{IC}_{25}, 98.91 \%$ at $\mathrm{IC}_{50}$, and $99.44 \%$ at $\mathrm{IC}_{75}$. Annexin $\mathrm{V} /$ propidium iodide (PI) flow cytometry analysis confirmed that ZnO NPs induce apoptosis in MCF-7 cells. The pro-apoptotic genes $p 53, p 21, B a x$, and JNK were upregulated, whereas anti-apoptotic genes $B c l-2, A K T 1$, and ERK1/2 were downregulated in a dose-dependent manner. The arrest and apoptosis of MCF-7 cells were induced by ZnO NPs through several signalling pathways.
\end{abstract}

Keywords: ZnO NPs; annexin V; cell cycle; apoptosis; Pichia kudriavzevii; green method

\section{Introduction}

Breast cancer is one of the most frequent types of cancers in women, and overall it is the second most common form of cancer worldwide. As many as $25 \%$ of cases of cancer (1.67 million cases) and $15 \%$ of deaths in women (522,000 individuals) were caused by forms of breast cancer, as reported by GLOBOCAN [1]. 
The balance lost between the proliferated cells and apoptosis is a hallmark that intensifies the failure of damaged cells to be wiped out via apoptosis. Activating apoptotic paths in cells affected by tumour is a crucial approach to cancer therapy. Several natural products that are considered potentially powerful sources of anticancer drugs apply anti-tumour effects by inducing apoptosis [2]. Extracellular or intracellular signals activate apoptosis, which in turn provokes numerous signals of vague contraction or DNA fragmentation [3]. Additionally, the deregulations that cause the initiation and development of cancers represent hundreds of genes or signalling cascades [4]. Furthermore, numerous genes like $p 53, p 21, J N K, B a x, B c l-2, A K T$, and ERK1/2 engage in apoptotic pathways. Induced by gene alterations engaging in mitosis and chromosome separation, $p 53$ is essential for cellular aging [5]. To keep the genome stable, cell cycle checkpoints, DNA repair, and apoptosis can be activated by $p 53$ [3]. The progress of the majority of malignancies is highly dependent on the change or loss of $p 53$ [6]. The transcription of $B c l-2$ family members, particularly $B c l-2$ and Bax, can also be controlled by $p 53$. In addition, cyclin-dependent kinase inhibitors or in other words, the transcription of $p 21$, can be activated by $p 53$ when DNA is damaged, which can affect the development of the cell cycle through an interaction with various transcription factors leading to apoptosis $[7,8]$. The overexpression of anti-apoptosis $\mathrm{Bcl}-2$ has been involved in various carcinomas [9].

The Jun N-terminal kinase (JNK) pathway plays an important role in apoptosis. Apoptosis can be triggered by the regulation of pro-apoptotic genes via different types of transcription factor transactivation signalling or through manipulation proteins of pro- and anti-apoptotic proteins in mitochondria [10]. Unlike the JNK pathway, the pathway of extracellular signal-regulated kinase (ERK) is relevant to the proliferation, survival, and differentiation of cells [11]. Meanwhile, cell survival, cell growth, and angiogenesis are regulated by the PI3-K/AKT pathway [12]. Apoptosis in cancerous cells is elicited by inhibition of the $A K T$ and ERK pathway [13].

Chemotherapy is one of the main systemic treatments for early breast cancer, and its use has led to an improvement in the survival of women diagnosed with breast cancer. However, the non-specific systemic delivery, causing damage to normal, unaffected tissue, is a major problem of chemotherapy drugs [14]. Nanomedicine has recently emerged as a better choice for treating some common cancers, resulting in many nanoparticles being used as treatment in cancer cell lines. Zinc oxide $(\mathrm{ZnO})$ shows biocompatibility compared to different materials [15]. ZnO is an inorganic compound listed as "Generally Recognized as Safe" (GRAS) by the USA Food and Drug Administration (FDA) (21CFR182.8991) [16]. Although $\mathrm{Zn}$ is a necessary trace element involved in some biological processes $[17,18]$, when its local concentration increases, as has been shown, it will kill cells [19]. It has been reported that $\mathrm{Zn}^{2+}$ considerably affects cancer cells, indicating gene expression reduction and apoptosis induction [20]. The induction of apoptosis by zinc in cancers appears to be cell type-specific [20]. Zn apoptosis effects indicate that $\mathrm{ZnO}$ nanostructures can be utilized as an agent for anticancer, providing a possible target for the development of anti-tumour agents [20]. What is more surprising in vitro observations is that cancer cells that are dramatically less toxic to normal cells can be preferentially killed by ZnO NPs [21].

The technique for synthesizing $\mathrm{ZnO}$ nano-sized materials is a challenge for attaining standard antitumour therapy. Our previous study investigated the antioxidant and antibacterial activity of biosynthesized ZnO NPs using a new strain of yeast (Pichia kudriavzevii GY1) [22]. In this study, $\mathrm{ZnO}$ NPs were examined to evaluate breast cancer cell (MCF-7) anti-proliferation activity. To our knowledge, no previous studies have reported the potential use of $\mathrm{ZnO}$ nanoparticles by $P$. kudriavzevii in breast cancer treatment (in the MCF-7 cell line). As a result, a better insight into the anticancer activities of $\mathrm{ZnO}$ NPs and the cytotoxic effects of their constituents can contribute to facilitating the improvement of auspicious cancer therapeutics for use in nanomedicine. 


\section{Materials and Methods}

\subsection{Cell Culture}

The human breast cancer cell line (MCF-7) utilized in this study was obtained from the American Culture Collection (ATCC, Rockville, MD, USA). Phenol-red-free Roswell Park Memorial Institute medium (RPMI 1640) with L-glutamine (Sigma-Aldrich, Steinheim, Germany), supplemented with 10\% foetal bovine serum (FBS) (PAA, Pasching, Austria) and 1\% penicillin-streptomycin (PAA, Pasching, Austria) were used to culture cells. Each experiment used cells with a passage number less than 20 . All cells were maintained at $37^{\circ} \mathrm{C}$ in a humidified incubator containing $5 \% \mathrm{CO}_{2}$.

\subsection{In Vitro Cytotoxicity Assay}

In vitro cytotoxicity study was determined using MTT assay [23]. Concisely, 96 well plates were used to seed cells at a density of $1 \times 10^{6}$ cells per $100 \mu \mathrm{L}$. Different concentrations of $\mathrm{ZnO}$ NPs $(0,62.5,125,250,500$, and $1000 \mu \mathrm{g} / \mathrm{mL})$ were applied to treat cells after incubation at $37^{\circ} \mathrm{C}$ for a period of a whole day. In addition, the cytotoxicity assay of tamoxifen was investigated in various concentrations $(0,6.25,12.5,25,50$, and $100 \mu \mathrm{g} / \mathrm{mL})$ [24]. A volume of $10 \mu \mathrm{L}$ of MTT solution was added to each well and further incubated for $24 \mathrm{~h}$ in relative humidity at $37{ }^{\circ} \mathrm{C}$ with $5 \% \mathrm{CO}_{2}$. RPMI-1640 media without any samples was used as a negative control. Tamoxifen is a breast cancer treatment drug that was used as a positive control for the MCF-7 cell line. Each concentration of $\mathrm{ZnO}$ NPs was assayed in triplicate. The percent cell viability was calculated by following equation [25]:

$$
\text { Cell viability }(\%)=\frac{\text { OD of Control }- \text { OD of } \mathrm{ZnO}-\mathrm{NP} \text { treatment }}{\text { OD of Control }} \times 100
$$

The $50 \%$ growth inhibition concentration $\left(\mathrm{IC}_{50}\right)$ was calculated from a plotted dose-response curve.

\subsection{Cell Cycle Analysis by Flow Cytometry}

Culture flask cells measuring $25 \mathrm{~cm}^{2}$ were used to seed the cultured cells at a density of $1 \times 10^{6}$ per $\mathrm{mL}$, allowing the cell to adhere to the flask wall overnight. Treated cells had concentrations of $\mathrm{ZnO}$ NPs capable of growth inhibition of 25,50 , and $75 \%\left(\mathrm{IC}_{25}, \mathrm{IC}_{50}\right.$, and $\mathrm{IC}_{75}$, respectively) within $24 \mathrm{~h}$. At $1000 \mathrm{rpm}$ for $10 \mathrm{~min}$, the treated and untreated (negative control) cells were collected and centrifuged. The supernatant was disposed of and cold phosphate buffered saline (PBS) was used to wash the pellet. Cells were re-suspended in $500 \mu \mathrm{L}$ PBS and subsequently fixed in $70 \%$ cold ethanol for at least $2 \mathrm{~h}$ at $-20^{\circ} \mathrm{C}$. Cells were centrifuged at $1000 \mathrm{rpm}$ for $5 \mathrm{~min}$, the supernatant was discarded, and the cells were washed with PBS. The supernatant was disposed of and the cells were incubated with a mixture of $500 \mu \mathrm{L}$ PI/RNase $(400 \mu \mathrm{L}$ propidium iodide and $100 \mu \mathrm{L}$ ribonuclease A). Before being analysed, stained cells were incubated in darkness for a period of $30 \mathrm{~min}$ at room temperature. BD LSRFortessa ${ }^{\text {TM }}$ Cell Analyzer (Becton Dickinson, San Diego, NJ, USA) determined the cell cycle profile for 10,000 events per sample. Analytical software BD FACSDavia ${ }^{\mathrm{TM}}$ data was presented by percentage of cells compared to the populations of the untreated control.

\subsection{Apoptosis Detection by Annexin V/Propidium Iodide Assay}

Referring to the manufacturer's protocol, Annexin V-FITC (Fluorescein isothiocyanate) was performed to determine cell death mode. The cells were seeded in $25 \mathrm{~cm}^{2}$ culture flasks and incubated at $37^{\circ} \mathrm{C}$ in a humidified, $5 \% \mathrm{CO}_{2}$ incubator atmosphere for $24 \mathrm{~h}$ to allow them to attach. Culture medium was discarded and cells were treated with $\mathrm{ZnO}$ NPs at $\mathrm{IC}_{25}, \mathrm{IC}_{50}$, and IC 75 for $24 \mathrm{~h}$. After incubation, detached and adherent cells were collected by combining the spent medium and trypsin-EDTA-treated cells. Harvesting of treated and untreated (negative control) cells was done by centrifugation (1000 rpm for $5 \mathrm{~min}$ ) and then they were washed twice using cold PBS. After the supernatant was discarded, the pellet was re-suspended in $1 \times$ binding buffer. Then, $5 \mu \mathrm{L}$ of annexin 
V-FITC and $10 \mu \mathrm{L}$ of propidium iodide were added to each suspension in order to stain the cells. Suspensions were then gently vortexed and incubated while in darkness at room temperature for 10 min. BD LSRFortessa ${ }^{\mathrm{TM}}$ Cell Analyzer (Becton Dickinson) measured the cell death induction.

\subsection{Gene Expression by quantitative real-time-PCR}

RNA extraction of untreated (negative control) and treated MCF-7 cells with different concentrations $\left(\mathrm{IC}_{25}, \mathrm{IC}_{50}\right.$, and $\left.\mathrm{IC}_{75}\right)$ of $\mathrm{ZnO}$ NPs was performed through using an RNeasy Mini kit (Qiagen, Inc., Valencia, CA, USA). The procedure was performed as per the manufacturer's instructions. These instructions were also used as the template for quantitative real-time-PCR (qRT-PCR) to synthesize cDNA from purified RNA with an $\mathrm{RT}^{2}$ First Strand Kit (Qiagen). To perform qRT-PCR, the Corbett Rotor-Gene 6000 (Qiagen) was utilized. Finally, a pre-mix with a final volume of $25 \mu \mathrm{L}$ was prepared, consisting of $12.5 \mu \mathrm{L}$ of RT $^{2}$ SYBR $^{\circledR}$ Green ROX ${ }^{\mathrm{TM}}$ FAST mastermix (Qiagen), $1 \mu \mathrm{L}$ of primers (RT ${ }^{2}$ qPCR Primer Assays, Qiagen), $1 \mu \mathrm{L}$ of cDNA, and $10.5 \mu \mathrm{L}$ RNase-free water. Table 1 shows the primer pairs of target genes and GAPDH that were chosen from the Primer Bank website (www.ncbi.nlm.nih.gov).

Table 1. Genes used in quantitative real-time-PCR (qRT-PCR).

\begin{tabular}{|c|c|c|}
\hline Genes & Forward Primer & Reverse Primer \\
\hline$p-53$ & 5'-AGGTGACACTATAGAATA-3' & 5'-GGGATATCACTCAGCATG-3' \\
\hline$p-21$ & $5^{\prime}$-AGGTGACACTATAGAATA-3' & 5'-GGGATATCACTCAGCATG-3' \\
\hline JNK & $5^{\prime}$-AGGTGACACTATAGAATA-3' & 5'-GTACGACTCACTATAGGG-3' \\
\hline Bax & 5'-AGGTGACACTATAGAATA-3' & 5'-GGGATATCACTCAGCATG-3' \\
\hline Bcl-2 & 5'-AGGTGACACTATAGAATA-3' & 5'-GGGATATCACTCAGCATG-3' \\
\hline AKT1 & 5'-AGGTGACACTATAGAATA-3' & 5'-GTACGACTCACTATAGGG-3' \\
\hline ERK $1 / 2$ & $5^{\prime}$-AGGTGACACTATAGAATA-3' & 5'-GTACGACTCACTATAGGG-3' \\
\hline GAPDH & $5^{\prime}$-AGGTGACACTATAGAATA-3' & 5'-GTACGACTCACTATAGGG-3' \\
\hline
\end{tabular}

The conditions of default PCR were as follows: the PCR conditions were set to $95{ }^{\circ} \mathrm{C}$ to activate the enzyme for $10 \mathrm{~min}$, and then 40 cycles for $15 \mathrm{~s}$ at $95^{\circ} \mathrm{C}$ (denaturation) were performed, followed by a 30-s cycle at $60{ }^{\circ} \mathrm{C}$ (annealing and synthesis). Finally, to check and justify the results, the dissociation curve was built right after the PCR run. The expression of all genes ( $p 53, p 21, B a x$, JNK, Bcl-2, AKT1, and $E R K 1 / 2)$ was compared with the housekeeping gene (GAPDH) using $2^{-\Delta \Delta \mathrm{Ct}}$ approach which is the

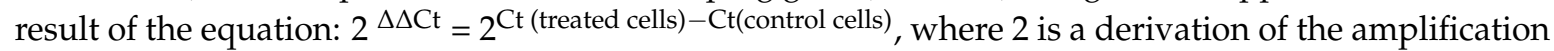
efficiency doubling the template in each cycle while ascending in strength.

\subsection{Statistical Analysis}

All data were analysed using Graph pad prism software version 7.01 (GraphPad Software Inc., La Jolla, CA, USA). At the level of $p \leq 0.05$, one-way analysis of variance (ANOVA) and differences were found to be significant.

\section{Results}

\subsection{MTT Assay}

The anticancer activity of ZnO NPs was investigated using the MTT assay on a human breast cancer cell line (MCF-7). MTT solution was mainly applied to stablish the applicability of cells, and it leads to mitochondrial dysfunction [23]. The ZnO NPs exhibited dose-dependent inhibition against the proliferation of cancer cell lines in the present study. After $24 \mathrm{~h}$ of treatment, the $\mathrm{IC}_{50}$ value was $121 \mu \mathrm{g} / \mathrm{mL}$ for MCF-7 cells (Figure 1A). Moreover, untreated cells were used as a negative control. Based on previous study, the ZnO NPs showed a selective anticancer effect, with no cytotoxicity in normal cells (Vero cell), and an $\mathrm{IC}_{50}$ greater than $100 \mu \mathrm{g} / \mathrm{mL}$ [22]. In addition, in reference to another 
study reported in the literature, it has recently been demonstrated that ZnO NPs induce the death of cancerous cells while having no cytotoxic effect on normal cells [26]. Other research also mentioned that $\mathrm{ZnO}$ NPs induce cell death in breast and prostate cancer cell lines, but have no major cytotoxic effects on normal breast and prostate cells [27]. Nevertheless, the $\mathrm{IC}_{50}$ of tamoxifen (a commercial chemotherapy drug) was used against MCF-7 cell line as a positive control, which showed that cytotoxicity in cancer cells is capable of being induced (Figure 1B). After $24 \mathrm{~h}$ of incubation the $\mathrm{IC}_{50}$ value for the MCF-7 cell line was $8 \mu \mathrm{g} / \mathrm{mL}$.
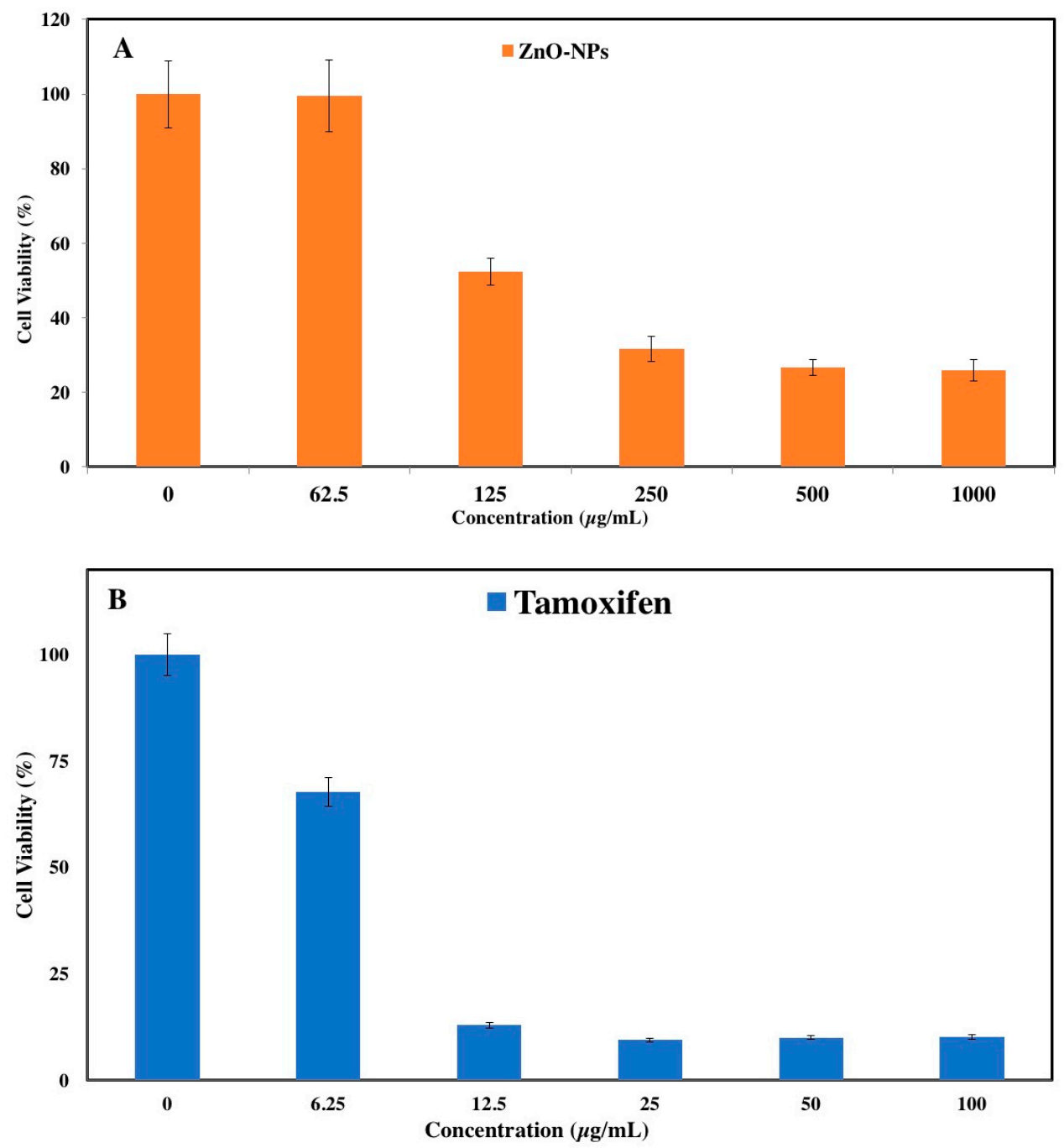

Figure 1. (A) Anti-proliferative activity of zinc oxide nanoparticles (ZnO NPs) with respect to MCF-7; (B) Effect of tamoxifen on MCF-7 cells.

\subsection{The Effect of Cell Cycle Distribution}

Through measuring the distribution of cell cycle, proliferation prevention was tested. After the MCF-7 cells were treated with ZnO NPs at different concentrations $\left(\mathrm{IC}_{25}, \mathrm{IC}_{50}\right.$, and $\left.\mathrm{IC}_{75}\right)$ for $24 \mathrm{~h}$, they were collected, fixed, and stained with propidium iodide, and the cell populations of each phase were determined via a flow cytometer. For cells treated with apoptosis-inducing agents, a subpopulation of cells appeared before the $G_{1}$ peak, which is called the sub- $G_{1}$ (apoptosis) peak. It is believed that this population with lesser stability is the outcome of endonuclease activation and subsequent DNA leakage of the cells. Since the immediate reduction in DNA content is not shown by necrotic cells, the difference between apoptotic and necrotic cells will be obvious. The degree or 
progression of apoptosis in a cell population can be measured by quantifying the ratio of cells in the sub- $\mathrm{G}_{1}$ in relation to the other phases [28]. As Figure 2 shows, the population of sub- $\mathrm{G}_{1}$ (indicating apoptotic cells) grew in a dose-dependent manner from $1.87 \%$ at $0 \mu \mathrm{g} / \mathrm{mL}$ (control) to $71.49 \%$ at $\mathrm{IC}_{25}, 98.91 \%$ at $\mathrm{IC}_{50}$, and $99.44 \%$ at $\mathrm{IC}_{75}$, after exposure to $\mathrm{ZnO}$ NPs for $24 \mathrm{~h}(p<0.0001)$. While the other portion of non-apoptotic cells exhibited no major changes, the population of $\mathrm{G}_{1}$ declined as the population of sub- $\mathrm{G}_{1}$ cells increased. When compared with the positive and negative control, the cell population of sub- $\mathrm{G}_{1}$ was shown to have an outstanding increase (Figure 2). On the other hand, in the S-phase it can be seen that the percentage of cells was increased compared to the control, in other words, the cells arrested. Deregulation of the cell cycle checkpoints could cause abnormal cell proliferation and cancer development [29]. Progression through the S-phase is controlled by the monitoring of replication checkpoints and moderation of DNA synthesis. In the event of DNA damage, this checkpoint prevents cell-cycle progression [30]. Hence, it was possible that the increment of cells in S-phase was due to the incorporation of NPs into damaged DNA during the process of DNA replication. On the other hand, tamoxifen is a selective oestrogen-receptor modulator [31] that has been used to treat both early and advanced breast cancer for more than three decades [32]. It has been thoroughly evaluated for the reduction of the risk of both invasive and non-invasive breast cancer in women at increased risk [33-35]. In this research, as a common commercial chemotherapy drug, tamoxifen was used as a positive control against the MCF-7 cell line. The MCF-7 cell is the most commonly used breast cancer cell line in the world, and was established in 1973 at the Michigan Cancer Foundation [36]. The popularity of MCF-7 is largely due to its exquisite hormone sensitivity through expression of the oestrogen receptor (ER), making it an ideal model to study hormone response [37]. According to tamoxifen results, it can be seen that the percentage of cells in $\mathrm{G}_{1}$ phase was increased and the number of cells in S-phase declined dramatically compared to the negative control. In other words, tamoxifen led to $G_{1}$ arrest and a decline in proliferation. One useful approach in cancer therapy is the induction of apoptosis. Many cellular molecular biological aspects like DNA fragmentation, cell shrinkage, and caspase cascade activation are shown in apoptotic cells [38]. Overall, all these results suggested that $\mathrm{ZnO} N \mathrm{~N}$-induced growth inhibitory effect is associated with the occurrence of apoptosis, more than cell cycle arrest. Thus, the apoptotic cell death of ZnO NPs was further analysed.

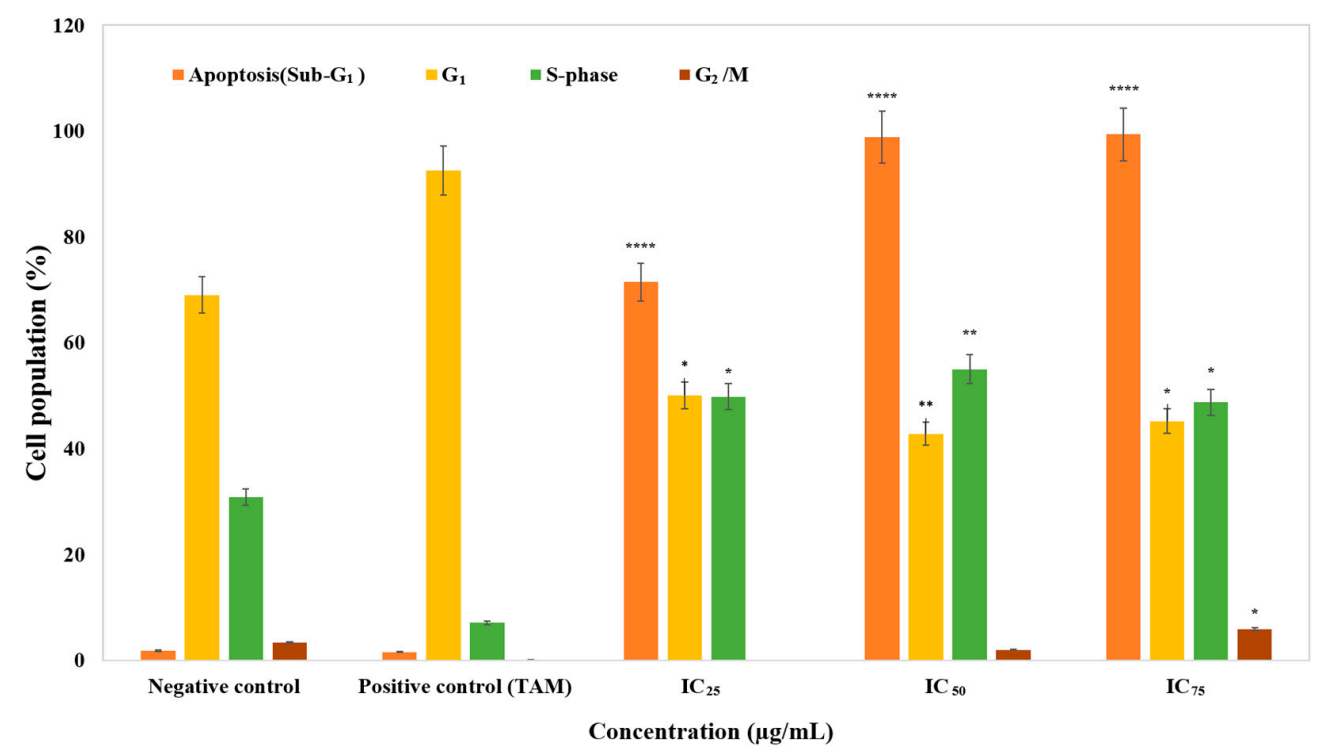

Figure 2. The cell cycles of MCF-7 cells treated with ZnO NPs. Cell populations are presented for each phase of the cell cycle for negative control (untreated cell), positive control (tamoxifen), and cells exposed to different concentrations of ZnO NPs for $24 \mathrm{~h}$. Data represent the mean \pm standard deviation (SD) $(n=3)$. More information in shown in Appendix A. ${ }^{*} p \leq 0.0 .5 ;{ }^{* *} p \leq 0.0 ;{ }^{* * *} p \leq 0.001$; $* * * * p \leq 0.0001$. TAM: Tamoxifen. 


\subsection{ZnO Nanoparticles Induced Apoptosis in MCF-7 Cells}

Flow cytometry was applied to quantitatively detect apoptosis rates through annexin V-FITC/PI staining. MCF-7 cell treatment with different concentrations $\left(\mathrm{IC}_{25}, \mathrm{IC}_{50}\right.$ and $\left.\mathrm{IC}_{75}\right)$ of $\mathrm{ZnO} \mathrm{NPs}$ was carried out for $24 \mathrm{~h}$. Stained cells can be distinguished into four groups, namely viable (annexin $\mathrm{V}^{-} \mathrm{PI}^{-}$), early apoptotic (annexin $\mathrm{V}^{+} \mathrm{PI}^{-}$), late apoptotic (annexin $\mathrm{V}^{+} \mathrm{PI}^{+}$) and necrotic (annexin $\mathrm{V}^{-} \mathrm{PI}^{+}$) cells, using a flow cytometer instrument. As illustrated in Figure 3, 98.60\% of negative control MCF-7 culture cells were viable. No apoptosis occurred after $24 \mathrm{~h}$ of incubation. Treating cells with $\mathrm{ZnO} N P s$, the viable cell percentage reduced significantly at $\mathrm{IC}_{25}, \mathrm{IC}_{50}$, and $\mathrm{IC}_{75}(27.94 \pm 5.69 \%$, $5.98 \pm 0.73 \%$ and $5.99 \pm 0.29 \%$ ) respectively (Figure 3 ). Furthermore, the percentage of cells at an early apoptotic stage increased significantly at all concentrations $\left(\mathrm{IC}_{25}(62.53 \pm 6.02 \%), \mathrm{IC}_{50}(68.32 \pm 2.10 \%)\right.$ and $\left.\mathrm{IC}_{75}(61.85 \pm 3.68 \%)\right)$ compared to the negative control $(0.36 \pm 0.54 \%)(p<0.0001)$. Figure 3 shows that the greater the increase in dosage, the greater the population of late apoptotic cells $(8.51 \pm 0.31 \%$, $24.47 \pm 1.18 \%, 30.50 \pm 3.07 \%$ ).

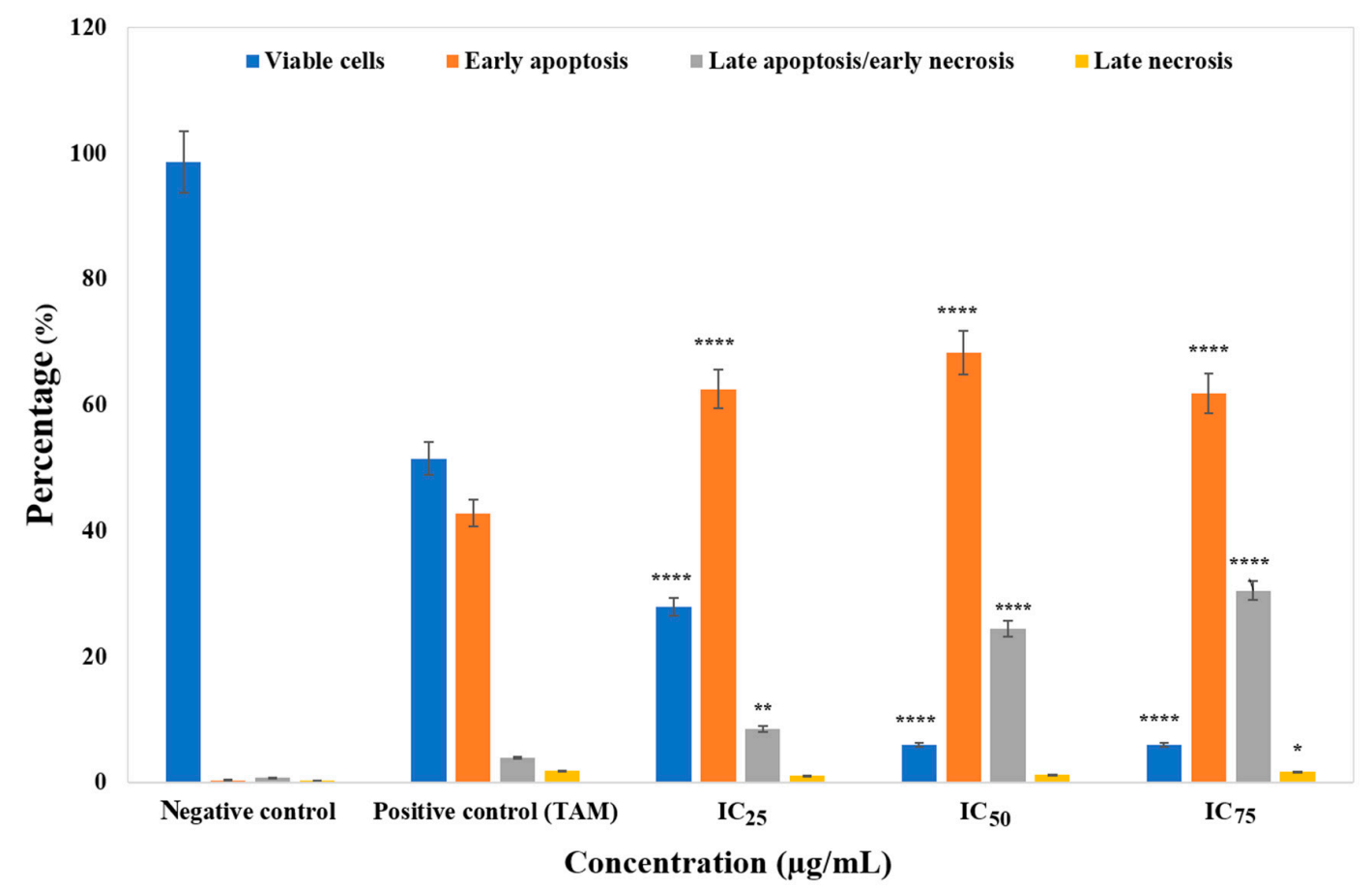

Figure 3. The percentage of viable, early apoptotic, late apoptotic/early necrotic, and late necrotic cells with respect to negative control (untreated), positive control (tamoxifen), and MCF-7 cells treated for $24 \mathrm{~h}$ as determined by a flow cytometer instrument. Cells were exposed to different concentrations of $\mathrm{ZnO}$ NPs for $24 \mathrm{~h}$. Data represent the mean $\pm \mathrm{SD}(n=3)$. More information on cell percentages is provided in Appendix B. ${ }^{*} p \leq 0.0 .5 ;{ }^{* *} p \leq 0.0 ;{ }^{* * *} p \leq 0.001 ;{ }^{* * * *} p \leq 0.0001$.

\subsection{Gene Expression Analysis of Apoptosis}

In this study, qRT-PCR was utilised to analyse the mRNA levels of apoptotic markers such as Bcl-2, Bax, p53, p21, AKT1, ERK1/2, and JNK in MCF-7 cells in the exposure of ZnO NPs at different concentrations $\left(\mathrm{IC}_{25}, \mathrm{IC}_{50}\right.$, and $\left.\mathrm{IC}_{75}\right)$ for $24 \mathrm{~h}$ (Figure 4 ). The expression of the $p 53$ gene in the treated MCF-7 cells was shown to be upregulated by 8.8 and 12.1 -fold using $\mathrm{IC}_{25}$ and $\mathrm{IC}_{50}(p<0.0001)$. The $p 21$ expression was notably upregulated $(p<0.0001)$ at $24 \mathrm{~h}$ by approximately $1.5,2.1$, and 4.9 -fold, at the tested concentrations of $\mathrm{IC}_{25}, \mathrm{IC}_{50}$, and $\mathrm{IC}_{75}$, respectively. Moreover, the expression level of total JNK increased significantly $\left(\mathrm{IC}_{25}: 4.5\right.$-fold, $\mathrm{IC}_{50}$ : 5.9-fold, and $\mathrm{IC}_{75}: 10.5$-fold) compared to the control in $24 \mathrm{~h}(p<0.0001)$. (Figure 4$)$. A significant increase in mRNA level of Bax was seen in MCF-7 cells after treatment with $\mathrm{IC}_{50}$ and $\mathrm{IC}_{75}(3.6$ and 5.2-fold) respectively $(p<0.0001)$. On the 
other hand, treated MCF-7 cells showed Bcl-2 downregulation by $\mathrm{ZnO} N P s$ at $\mathrm{IC}_{25}$ and $\mathrm{IC}_{50}$, by -6.6 and -13.5 fold, respectively. Similarly, ZnO NPs had a major effect on the expression of $A K T 1$ in MCF-7 cells, since it decreased the levels of $A K T 1$ with $\mathrm{IC}_{25}, \mathrm{IC}_{50}$, and $\mathrm{IC}_{75}$ concentrations by -5.08 , -8.6 and -9.9 fold, respectively. Figure 4 shows that the expression of ERK1/2 of MCF-7 cells treated with $\mathrm{IC}_{25}, \mathrm{IC}_{50}$, and $\mathrm{IC}_{75}$ of $\mathrm{ZnO}$ NPs was substantially downregulated $(p<0.0001)$ at $24 \mathrm{~h}$ by $-6.7-$, -3.2 , and -14.2 fold, respectively, compared to control.

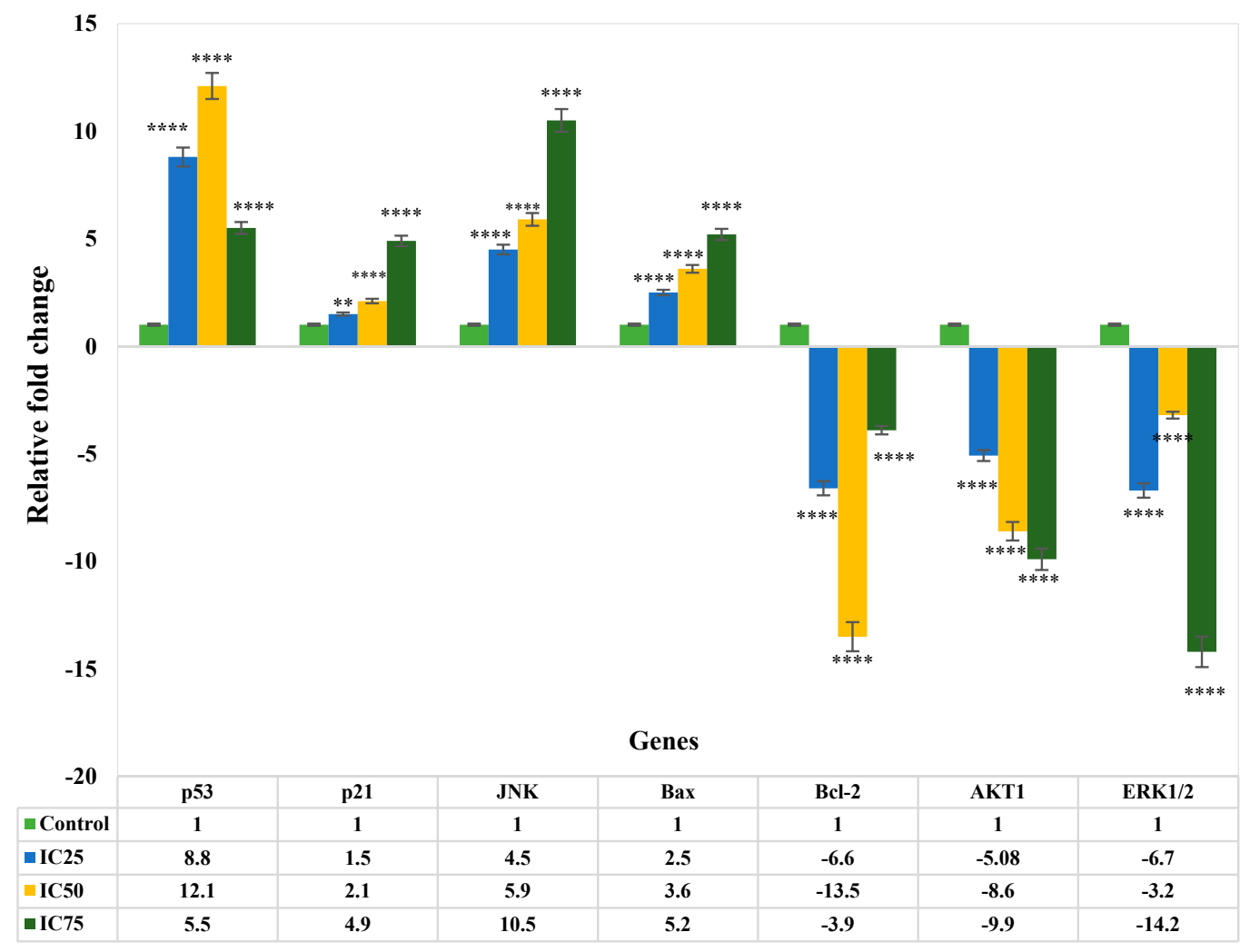

Figure 4. Gene expression levels in MCF-7 cells following treatment with $\mathrm{ZnO}$ Ps. Relative fold change of gene expression in $\mathrm{ZnO} N$ P-treated cells at $24 \mathrm{~h}$, in comparison to the control. The values represent the mean $\pm \operatorname{STD}(n=3)$. ${ }^{*} p \leq 0.0 .5 ;{ }^{* *} p \leq 0.0{ }^{* * *} p \leq 0.001 ;{ }^{* * * *} p \leq 0.0001$.

\section{Discussion}

In the present study, the green synthesis of ZnO NPs showed strong cytotoxic characteristics against MCF-7 cells (Figure 1). The cell viability of breast cancer cells noticeably decreases with an increase in $\mathrm{ZnO} \mathrm{NP}$ concentration. There are various parameters that can be considered to study the cytotoxic effect of nanoparticles, such as shape, size, surface charge, and dissolution of NPs [39]. Moreover, Wahab and colleagues also reported the viability of cancer cell line was reduced by $\mathrm{ZnO} \mathrm{NPs}$ and that the degree of reduction was concentration/dose-dependent [40]. In another study, the investigation of the toxicity effect of ZnO NPs using the green approach was compared with the $\mathrm{ZnO} \mathrm{NP}$ commercial type. They reported that the cytotoxicity effect of green synthesis was much better compared to commercial type against the MCF-7 cell line [41]. In addition, Sivaraj et al. reported that the cytotoxicity of the ZnO NPs was evaluated against MCF-7 at various concentrations $(6.5-100 \mu \mathrm{g} / \mathrm{mL})$. Moreover, by increasing concentration the toxicity effect was increased [42].

The cell cycle includes interphases $\left(G_{1}, S\right.$, and $\left.G_{2}\right)$ and mitosis $(M)$. Cells increase in size, produce RNA, and synthesize proteins for DNA formation during the $G_{1}$ period. In normal conditions, during the $S$ phase DNA replicate and cells continue to grow; new proteins are produced at the $G_{2}$ phase. It is 
at the M stage where nuclear and cytoplasmic divisions take place [43]. Moreover, one strategy in the progression of anticancer drugs is the regulation of cancer cell cycle [44]. According to the result of cell cycle analysis, determined by analysis from flow cytometry, ZnO NPs can induce apoptosis in MCF-7. Based on our result, inhibition of the cell growth with $\mathrm{IC}_{50}$ and $\mathrm{IC}_{75} \mathrm{ZnO}$ NPs at $24 \mathrm{~h}$ (Figure 2) was due to induction of apoptosis at the sub-G $\mathrm{G}_{1}$ phase. Wahab et al. reported that MCF-7 cells which were treated with $\mathrm{ZnO}$ NPs showed a significant induction of apoptosis. This was shown by the fact that roughly $26 \%$ of treated cells appeared in the sub- $\mathrm{G}_{1}$ phase of the cell cycle, as compared to $2.8 \%$ of the untreated control cells. The increase in the concentration of nanoparticles improved the degree of apoptosis [40].

The annexin V-FITC/PI flow cytometry analysis stablished the induction of apoptosis by ZnO NPs in MCF-7 cells (Figure 3). Necrosis and apoptosis are two distinct modes of cell death which differ in morphology, mechanisms, and incidence [45]. Cell detachment and shrinkage, bleb separation (protrusions of the plasma membranes) and the formation of apoptotic bodies packed densely with cellular organelles and nuclear fragments are the main initiators of apoptosis [46]. In vivo, apoptosis does not go through lysis bodies, as macrophages or adjacent cells surround them. Conversely, in vitro, due to the absence of phagocytes, the formed apoptosis bodies will finally swell and the process of apoptosis moves on to an autolytic necrotic outcome [47-49]. Here, the term late apoptosis or secondary necrosis, which is the natural outcome of the complete apoptotic program, is used to describe dead cells that have reached this state via apoptotic programming as named in $[49,50]$. In apoptosis, the cytoplasmic and the lysosomal membrane remain intact [49]. Necrosis, on the other hand, has been characterized as a passive, accidental cell death process that elicits uncontrolled inflammatory cellular responses [51]. The most significant features of necrosis are cell swelling, lysosomal membrane permeabilisation, and cell membrane permeabilisation [49]. As apoptosis is considered to be a regulated and a controlled process, its occurrence during cancer treatment has received great attention $[52,53]$.

The possible mechanism of death of the MCF-7 cells after exposure to the ZnO NPs was further explored by annexin V/PI assay, which measures apoptosis. In apoptotic cells, the membrane phospholipid phosphatidylserine (PS) is translocated from the inner to the outer leaflet of the plasma membrane [54]. This translocation of PS to the outer leaflet of the lipid bilayer occurs very early in the apoptotic process [48]. In a calcium-dependent manner, annexin $\mathrm{V}$, which is an internal protein in the human body and has a high affinity to bind to PS, can detect the PS that has been exposed. This binding of annexin V to PS can be detected using fluorescently-labelled annexin V and a flow cytometer. PI, which is used to differentiate applicable from inapplicable cells, is a standard flow cytometrically-applicable probe. PI is not included in applicable cells with intact membranes. However, the membranes of the dead or damaged cells are permeable for PI staining [55]. Therefore, staining with fluorochromes, including FITC-conjugated annexin V (FITC-annexin V) is typically used in conjunction with PI [56]. The analysis revealed that with 24 -h treatment at varying concentrations, i.e., $\mathrm{IC}_{25}, \mathrm{IC}_{50}$, and $\mathrm{IC}_{75}$, ZnO NPs yielded higher percentages of early apoptotic cells, while only a low percentage of cells died via the necrosis pathway, as dying cells by apoptosis were finally degraded to necrotic ones as a result of losing their ability to repair DNA in late apoptosis. Overall, this result suggested that ZnO NPs induced the early apoptotic rather than necrotic pathway. In a similar study, Deng and colleagues also reported, via annexin V-FITC and PI assay, that ZnO NPs can induce apoptosis in mouse neural stem cells (NSCs). After a whole day of treatment with ZnO NPs, the number of apoptotic cells reached $55.6 \%$ [57].

The apoptosis induction by ZnO NPs in investigating molecular pathways was carried out utilising the qRT-PCR technique. Expression of $p 53, p 21, J N K$, and Bax was upregulated, while in contrast, $B c l-2, A K T 1$, and ERK 1/2 was downregulated following treatment with ZnO NPs. The tumour suppressors $p 53$ and $p 21$ of MCF-7 cells were upregulated in the present research (Figure 4). The upregulation of $p 53$ by ZnO NPs has been suggested to trigger 21 protein accumulation, resulting in a sub- $\mathrm{G}_{1}$ phase cell cycle for apoptosis induction in MCF-7 cells [58-60]. $p 53 / p 21$ is involved in cell 
cycle control, apoptosis, and genomic stability maintenance. Upon DNA damage, $p 53$ starts repairing the damage by inducing cell cycle arrest at different checkpoints. Then, apoptosis kills those cells that are not repaired [59].

Involvement from members of the $M A P K$ family, such as $E R K$ and $J N K$, is also crucial in regulating cancer cell proliferation. The key factors in intrinsic pathways can indirectly be promoted by ZnO NPs modulating ERK. Throughout this study, apoptosis was constantly triggered by ERK inhibition [61]. The activation of $J N K$, as a stress-responsive kinase, was reported to induce apoptosis in a variety of cancer cells, including MCF-7 cells [62]. Following treatment with ZnO NPs, the JNK gene was upregulated by over 5-fold in this research. It can be suggested that bioactive component excitement in ZnO NPs, which in turn induces growth inhibition and apoptosis in MCF-7 cells, can activate JNK [63]. Hence, modulating the expression of the Bcl-2 gene might be the mechanism through which ZnO NPs induce apoptosis. By preventing mitochondrial membrane potential loss, $B c l-2$ group members have long been claimed to have a pivotal role in cell viability maintenance. Overexpression of $B c l-2$ stops apoptosis, whereas upregulation of Bax induces apoptosis in cancer cells [64,65].

In our study, the mRNA expression level of Bax was upregulated, with downregulation of $\mathrm{Bcl}-2$ following treatment with $\mathrm{ZnO}$ NPs. The elevated $B a x / B c l-2$ ratio and the depolarization of mitochondrial membrane potential suggest that ZnO NPs induced apoptosis is mitochondria-dependent.

The expression of $A K T 1$ gene (Figure 4) was downregulated in this research, suggesting $A K T$ pathway involvement in $\mathrm{ZnO} \mathrm{NP}$-induced apoptosis. The control of balance between survival and apoptosis is facilitated by a serine-threonine kinase, i.e., $A K T$ [66].

One correlation study at King Saud University (Saudi Arabia) showed the effect of ZnO NPs on mRNA levels of apoptotic markers by qRT-PCR. After treatment of HepG2 cells (liver cancer cells) with ZnO NPs, mRNA levels of the cell cycle checkpoint protein $p 53$ and the pro-apoptotic protein Bax were shown to be upregulated. The mRNA expression levels of tumour suppression gene $p 53$ was reported to be 1.9-fold higher and their levels of pro-apoptotic gene Bax as well as anti-apoptotic gene $B c l-2$ were reduced in the exposed cells compared to the untreated cells [40].

In other research, the expression of pro-apoptotic (Bax, Noxa and Puma) and anti-apoptotic (Bcl-xl) genes of human epidermal keratinocytes (HaCaT) after 24-h exposure with ZnO NPs was evaluated. Based on the results, expression of the pro-apoptotic genes increased significantly, while the expression of the anti-apoptotic gene decreased. According to the findings of this research, $\mathrm{ZnO}$ NPs induced cell cycle arrest at G2/M, which was associated with changes in epigenetic and was accompanied by p53-Bax mitochondrial pathway-mediated apoptosis [67].

\section{Conclusions}

The anti-cancer effects of ZnO NPs on MCF-7 cell were shown in varying dosages. Through the inhabitation of cell proliferation of the cancer cells, the effect was mediated. The underlying mechanisms include stimulation of cell-specific $\mathrm{G}_{0} / \mathrm{G}_{1}, \mathrm{~S}$, and $\mathrm{G}_{2} / \mathrm{M}$ cell cycle arrest, and the induction of apoptosis through both extrinsic and intrinsic apoptotic pathways. In addition, the $\mathrm{ZnO}$ NP-induced apoptosis in MCF-7 cells is likely to reflect downregulation of Bcl-2 and AKT1 and ERK1/2, while p21, p53, JNK and Bax were upregulated. The hypothesis that green synthesis of ZnO NPs using the new strain of yeast $P$. kudriavzevii GY1 can potentially be used in certain types of anti-cancer therapy is supported by this research.

Acknowledgments: The authors are grateful to the Department of Bioprocess Technology of the Faculty of Biotechnology and Biomolecular Sciences, and the Institute of Bioscience at Universiti Putra Malaysia for their laboratory facilities.

Author Contributions: A.B.M. performed experiments, analysed data, and wrote the manuscript. M.M. contributed to the writing of the manuscript. R.M. and S.A. supervised research and edited the manuscript. R.A.R., A.B.A., and M.N. analysed the data.

Conflicts of Interest: The authors declare no conflict of interest. 


\section{Appendix A}

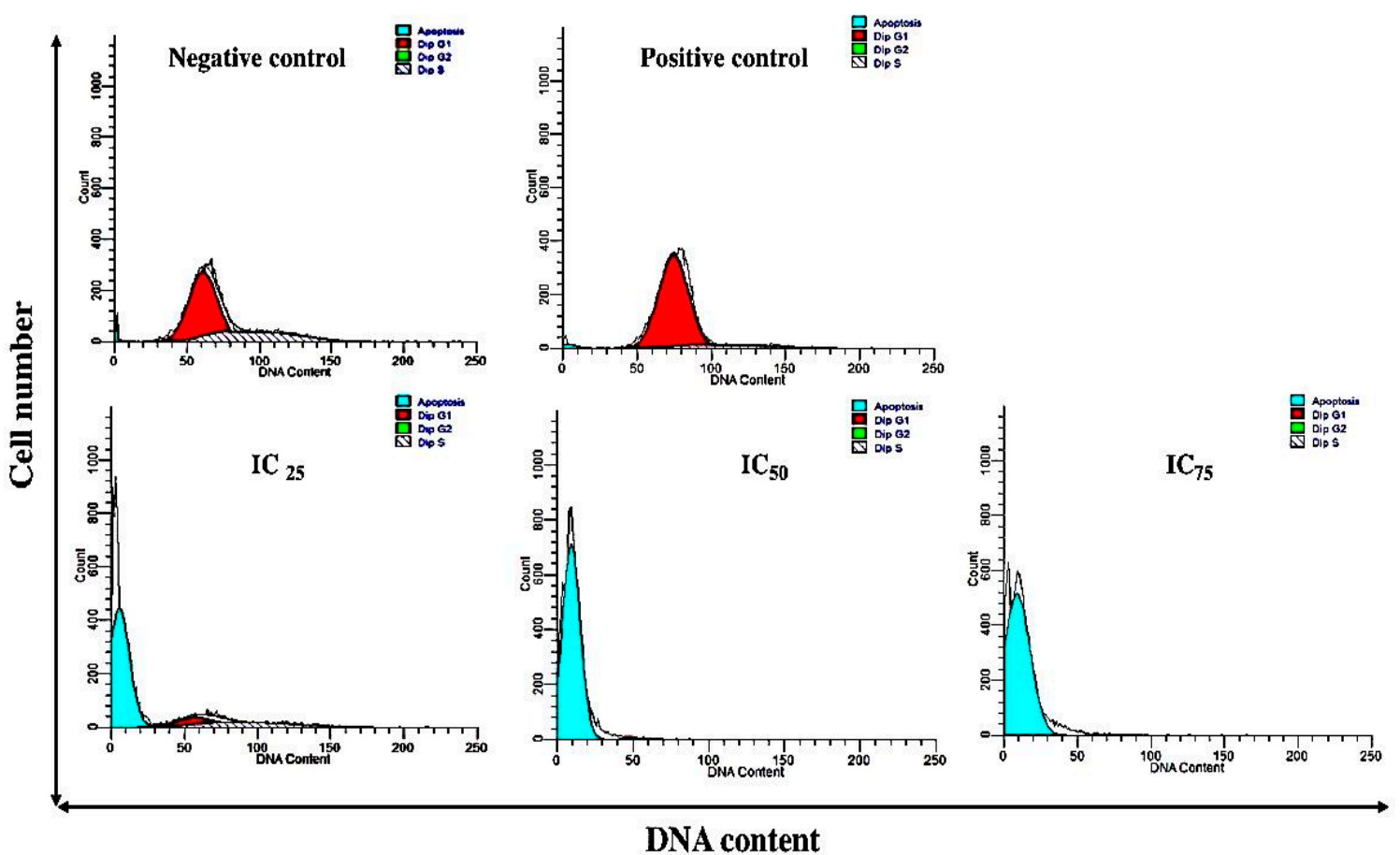

Figure A1. Shows the cell cycle of MCF-7 cells treated with ZnO NPs.

\section{Appendix B}
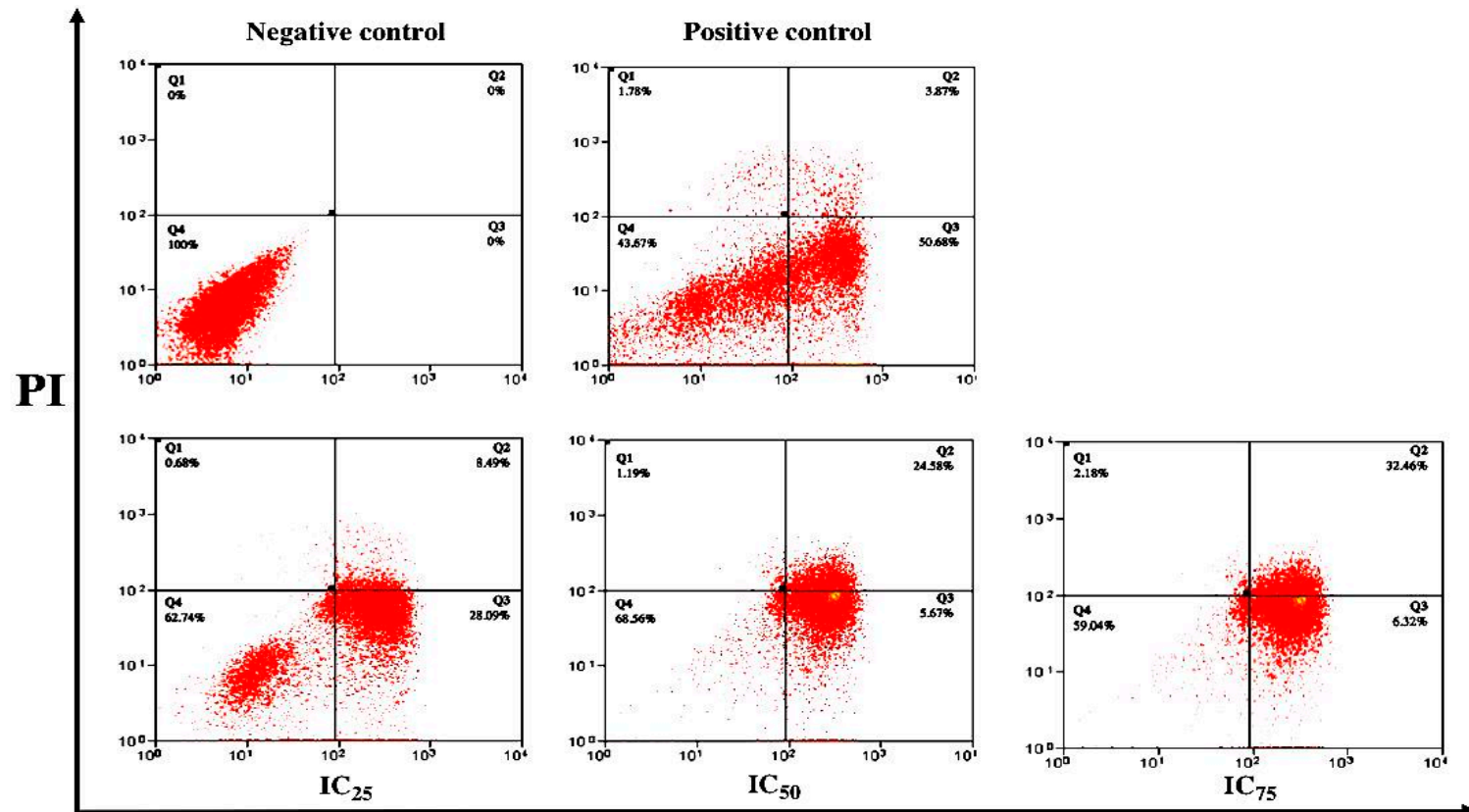

Annexin V-FITC

Figure A2. The percentage of viable, early apoptotic, late apoptotic/early necrotic, and late necrotic cells of negative control (untreated), positive control (tamoxifen) and MCF-7 treated cells for $24 \mathrm{~h}$ as determined by a flow cytometer instrument. 


\section{References}

1. Wolff, A.C.; Hammond, M.E.H.; Hicks, D.G.; Dowsett, M.; McShane, L.M.; Allison, K.H.; Hanna, W. Recommendations for human epidermal growth factor receptor 2 testing in breast cancer: American Society of Clinical Oncology/College of American Pathologists clinical practice guideline update. J. Clin. Oncol. 2013, 31, 3997-4013. [CrossRef] [PubMed]

2. Elkady, A.I.; Abuzinadah, O.A.; Baeshen, N.A.; Rahmy, T.R. Differential control of growth, apoptotic activity, and gene expression in human breast cancer cells by extracts derived from medicinal herbs Zingiber officinale. J. BioMed. Res. 2012, 2012. [CrossRef]

3. Ahmad, J.; Ahamed, M.; Akhtar, M.J.; Alrokayan, S.A.; Siddiqui, M.A.; Musarrat, J.; Al-Khedhairy, A.A. Apoptosis induction by silica nanoparticles mediated through reactive oxygen species in human liver cell line HepG2. Toxicol. Appl. Pharmacol. 2012, 259, 160-168. [CrossRef] [PubMed]

4. Teiten, M.-H.; Eifes, S.; Dicato, M.; Diederich, M. Curcumin-The paradigm of a multi-target natural compound with applications in cancer prevention and treatment. Toxins 2010, 2, 128-162. [CrossRef] [PubMed]

5. Fan, Y.; Lu, H.; An, L.; Wang, C.; Zhou, Z.; Feng, F.; Ma, H.; Xu, Y.; Zhao, Q. Effect of active fraction of Eriocaulon sieboldianum on human leukemia K562 cells via proliferation inhibition, cell cycle arrest and apoptosis induction. Environ. Toxicol. Pharmacol. 2016, 43, 13-20. [CrossRef] [PubMed]

6. Lohrum, M.A.E.; Vousden, K.H. Regulation and function of the p53-related proteins: Same family, different rules. Trends Cell Biol. 2000, 10, 197-202. [CrossRef]

7. Gartel, A.L.; Tyner, A.L. The role of the cyclin-dependent kinase inhibitor p21 in apoptosis 1 supported in part by NIH grant R01 DK56283 (to ALT) for the p21 research and Campus Research Board and Illinois Department of Public Health Penny Severns Breast and Cervical Cancer grant. Mol. Cancer Ther. 2002, 1, 639-649. [PubMed]

8. Piccolo, M.T.; Crispi, S. The dual role played by p21 may influence the apoptotic or anti-apoptotic fate in cancer. J. Can. Res. Updates 2012, 1, 189-202.

9. Guo, R.; Overman, M.; Chatterjee, D.; Rashid, A.; Shroff, S.; Wang, H.; Katz, M.H.; Fleming, J.B.; Varadhachary, G.R.; Abbruzzese, J.L. Aberrant expression of p53, p21, cyclin D1, and Bc12 and their clinicopathological correlation in ampullary adenocarcinoma. Hum. Pathol. 2014, 45, 1015-1023. [CrossRef] [PubMed]

10. Dhanasekaran, D.N.; Reddy, E.P. JNK signaling in apoptosis. Oncogene 2008, 27, 6245-6251. [CrossRef] [PubMed]

11. Roberts, P.J.; Der, C.J. Targeting the Raf-MEK-ERK mitogen-activated protein kinase cascade for the treatment of cancer. Oncogene 2007, 26, 3291-3310. [CrossRef] [PubMed]

12. Manning, B.D.; Cantley, L.C. AKT/PKB signaling: Navigating downstream. Cell 2007, 129, 1261-1274. [CrossRef] [PubMed]

13. Roy, S.K.; Srivastava, R.K.; Shankar, S. Inhibition of PI3K/AKT and MAPK/ERK pathways causes activation of FOXO transcription factor, leading to cell cycle arrest and apoptosis in pancreatic cancer. J. Mol. Signal. 2010, 5, 10. [CrossRef] [PubMed]

14. Brigger, I.; Dubernet, C.; Couvreur, P. Nanoparticles in cancer therapy and diagnosis. Adv. Drug Deliv. Rev. 2002, 54, 631-651. [CrossRef]

15. Arakelova, E.R.; Grigoryan, S.G.; Arsenyan, F.G.; Babayan, N.S.; Grigoryan, R.M.; Sarkisyan, N.K. In vitro and in vivo anticancer activity of nanosize zinc oxide composites of doxorubicin. Int. J. Med. Heal. Pharm. Biomed. Eng. 2014, 8, 33-38.

16. Espitia, P.J.P.; de Fátima Ferreira Soares, N.; dos Reis Coimbra, J.S.; de Andrade, N.J.; Cruz, R.S.; Medeiros, E.A.A. Zinc oxide nanoparticles: Synthesis, antimicrobial activity and food packaging applications. Food Bioprocess Technol. 2012, 5, 1447-1464. [CrossRef]

17. Prasad, A.S. Zinc in human health: Effect of zinc on immune cells. Mol. Med. 2008, 14, 353-357. [CrossRef] [PubMed]

18. Vallee, B.L.; Auld, D.S. Zinc coordination, function, and structure of zinc enzymes and other proteins. Biochemistry 1990, 29, 5647-5659. [CrossRef] [PubMed]

19. Dineley, K.E.; Votyakova, T.V.; Reynolds, I.J. Zinc inhibition of cellular energy production: Implications for mitochondria and neurodegeneration. J. Neurochem. 2003, 85, 563-570. [CrossRef] [PubMed] 
20. Franklin, R.B.; Costello, L.C. The important role of the apoptotic effects of zinc in the development of cancers. J. Cell. Biochem. 2009, 106, 750-757. [CrossRef] [PubMed]

21. Hanley, C.; Layne, J.; Punnoose, A.; Reddy, K.M.; Coombs, I.; Coombs, A.; Feris, K.; Wingett, D. Preferential killing of cancer cells and activated human T cells using ZnO nanoparticles. Nanotechnology 2008, 19, 295103. [CrossRef] [PubMed]

22. Moghaddam, A.B.; Moniri, M.; Azizi, S.; Rahim, R.A.; Ariff, A.B.; Saad, W.Z.; Namvar, F.; Navaderi, M.; Mohamad, R. Biosynthesis of ZnO nanoparticles by a new Pichia kudriavzevii yeast strain and evaluation of their antimicrobial and antioxidant activities. Molecules 2017, 22, 872. [CrossRef] [PubMed]

23. Mosmann, T. Rapid colorimetric assay for cellular growth and survival: Application to proliferation and cytotoxicity assays. J. Immunol. Methods 1983, 65, 55-63. [CrossRef]

24. Foo, J.B.; Yazan, L.S.; Tor, Y.S.; Armania, N.; Ismail, N.; Imam, M.U.; Yeap, S.K.; Cheah, Y.K.; Abdullah, R.; Ismail, M. Induction of cell cycle arrest and apoptosis in caspase-3 deficient MCF-7 cells by Dillenia suffruticosa root extract via multiple signalling pathways. BMC Complement. Altern. Med. 2014, 14, 197. [CrossRef] [PubMed]

25. Badakhshan, M.P.; Sreenivasan, S.; Jegathambigai, R.N.; Surash, R. Anti-leukemia activity of methanolic extracts of Lantana camara. Pharmacogn. Res. 2009, 1, 274-279.

26. Taccola, L.; Raffa, V.; Riggio, C.; Vittorio, O.; Iorio, M.C.; Vanacore, R.; Pietrabissa, A.; Cuschieri, A. Zinc oxide nanoparticles as selective killers of proliferating cells. Int. J. Nanomed. 2011, 6, 1129-1140.

27. Ostrovsky, S.; Kazimirsky, G.; Gedanken, A.; Brodie, C. Selective cytotoxic effect of ZnO nanoparticles on glioma cells. Nano Res. 2009, 2, 882-890. [CrossRef]

28. Luk, S.C.-W.; Siu, S.W.-F.; Lai, C.-K.; Wu, Y.-J.; Pang, S.-F. Cell cycle arrest by a natural product via G2/M checkpoint. Int. J. Med. Sci. 2005, 2, 64-69. [CrossRef] [PubMed]

29. Chen, L.; Zhang, X.; Chen, J.; Zhang, X.; Fan, H.; Li, S.; Xie, P. NF-kB plays a key role in microcystin-RR-induced HeLa cell proliferation and apoptosis. Toxicon 2014, 87, 120-130. [CrossRef] [PubMed]

30. Dickson, M.A.; Schwartz, G.K. Development of cell-cycle inhibitors for cancer therapy. Curr. Oncol. 2009, 16, 36-43. [PubMed]

31. Valdiglesias, V.; Costa, C.; Kiliç, G.; Costa, S.; Pásaro, E.; Laffon, B.; Teixeira, J.P. Neuronal cytotoxicity and genotoxicity induced by zinc oxide nanoparticles. Environ. Int. 2013, 55, 92-100. [CrossRef] [PubMed]

32. Group, E.B.C.T.C. Tamoxifen for early breast cancer: An overview of the randomised trials. Lancet 1998, 351, 1451-1467.

33. Cuzick, J. First results from the International Breast Cancer Intervention Study (IBIS-I): A randomised prevention trial. Lancet 2002, 360, 817-824. [PubMed]

34. Fisher, B.; Costantino, J.P.; Wickerham, D.L.; Redmond, C.K.; Kavanah, M.; Cronin, W.M.; Vogel, V.; Robidoux, A.; Dimitrov, N.; Atkins, J. Tamoxifen for prevention of breast cancer: Report of the National Surgical Adjuvant Breast and Bowel Project P-1 Study. JNCI J. Natl. Cancer Inst. 1998, 90, 1371-1388. [CrossRef] [PubMed]

35. Fabian, C.J.; Kimler, B.F. Selective estrogen-receptor modulators for primary prevention of breast cancer. J. Clin. Oncol. 2005, 23, 1644-1655. [CrossRef] [PubMed]

36. Soule, H.D.; Vazquez, J.; Long, A.; Albert, S.; Brennan, M. A human cell line from a pleural effusion derived from a breast carcinoma 2. J. Natl. Cancer Inst. 1973, 51, 1409-1416. [CrossRef] [PubMed]

37. Levenson, A.S.; Jordan, V.C. MCF-7: The first hormone-responsive breast cancer cell line. Cancer Res. 1997, 57, 3071-3078. [PubMed]

38. Germain, M.; Affar, E.B.; D'Amours, D.; Dixit, V.M.; Salvesen, G.S.; Poirier, G.G. Cleavage of automodified poly (ADP-ribose) polymerase during apoptosis evidence for involvement of caspase-7. J. Biol. Chem. 1999, 274, 28379-28384. [CrossRef] [PubMed]

39. Hanley, C.; Thurber, A.; Hanna, C.; Punnoose, A.; Zhang, J.; Wingett, D.G. The influences of cell type and $\mathrm{ZnO}$ nanoparticle size on immune cell cytotoxicity and cytokine induction. Nanoscale Res. Lett. 2009, 4, 1409-1420. [CrossRef] [PubMed]

40. Wahab, R.; Siddiqui, M.A.; Saquib, Q.; Dwivedi, S.; Ahmad, J.; Musarrat, J.; Al-Khedhairy, A.A.; Shin, H.-S. $\mathrm{ZnO}$ nanoparticles induced oxidative stress and apoptosis in HepG2 and MCF-7 cancer cells and their antibacterial activity. Colloids Surf. B Biointerfaces 2014, 117, 267-276. [CrossRef] [PubMed] 
41. Prashanth, G.K.; Prashanth, P.A.; Bora, U.; Gadewar, M.; Nagabhushana, B.M.; Ananda, S.; Krishnaiah, G.M.; Sathyananda, H.M. In vitro antibacterial and cytotoxicity studies of $\mathrm{ZnO}$ nanopowders prepared by combustion assisted facile green synthesis. Karbala Int. J. Mod. Sci. 2015, 1, 67-77.

42. Sivaraj, R.; Rahman, P.K.S.M.; Rajiv, P.; Venckatesh, R. Biogenic zinc oxide nanoparticles synthesis using Tabernaemontana Divaricate leaf extract and its anticancer activity against MCF-7 breast cancer cell Lines. Int. Conf. Adv. Agric. Biol. Environ. Sci. 2014, 1, 83-85.

43. Vaja, F.; Guran, C.; Ficai, D.; Ficai, A.; Oprea, O. Cytotoxic effects of ZnO nanoparticles incorporated in mesoporous silica. UPB Sci. Bull. 2014, 76, 55-66.

44. Carnero, A. Targeting the cell cycle for cancer therapy. Br. J. Cancer 2002, 87, 129-133. [CrossRef] [PubMed]

45. Dive, C.; Gregory, C.D.; Phipps, D.J.; Evans, D.L.; Milner, A.E.; Wyllie, A.H. Analysis and discrimination of necrosis and apoptosis (programmed cell death) by multiparameter flow cytometry. Biochim. Biophys. Acta (BBA)-Mol. Cell Res. 1992, 1133, 275-285. [CrossRef]

46. Kerr, J.F.R.; Winterford, C.M.; Harmon, B.V. Apoptosis. Its significance in cancer and cancer therapy. Cancer 1994, 73, 2013-2026. [CrossRef]

47. Lincz, L.F. Deciphering the apoptotic pathway: All roads lead to death. Immunol. Cell Biol. 1998, 76, 1-19. [CrossRef] [PubMed]

48. Fadok, V.A.; Voelker, D.R.; Campbell, P.A.; Cohen, J.J.; Bratton, D.L.; Henson, P.M. Exposure of phosphatidylserine on the surface of apoptotic lymphocytes triggers specific recognition and removal by macrophages. J. Immunol. 1992, 148, 2207-2216. [PubMed]

49. Silva, M.T. Secondary necrosis: The natural outcome of the complete apoptotic program. FEBS Lett. 2010, 584, 4491-4499. [CrossRef] [PubMed]

50. Wyllie, A.H.; Kerr, J.F.R.; Currie, A.R. Cell death: The significance of apoptosis. Int. Rev. Cytol. 1980, 68, 251-306. [PubMed]

51. Fink, S.L.; Cookson, B.T. Apoptosis, pyroptosis, and necrosis: Mechanistic description of dead and dying eukaryotic cells. Infect. Immun. 2005, 73, 1907-1916. [CrossRef] [PubMed]

52. Guerriero, J.L.; Ditsworth, D.; Fan, Y.; Zhao, F.; Crawford, H.C.; Zong, W.-X. Chemotherapy induces tumor clearance independent of apoptosis. Cancer Res. 2008, 68, 9595-9600. [CrossRef] [PubMed]

53. Fulda, S. Tumor resistance to apoptosis. Int. J. Cancer 2009, 124, 511-515. [CrossRef] [PubMed]

54. Van Engeland, M.; Nieland, L.J.W.; Ramaekers, F.C.S.; Schutte, B.; Reutelingsperger, C.P.M. Annexin V-affinity assay: A review on an apoptosis detection system based on phosphatidylserine exposure. Cytometry 1998, 31, 1-9. [CrossRef]

55. Vermes, I.; Haanen, C.; Steffens-Nakken, H.; Reutellingsperger, C. A novel assay for apoptosis flow cytometric detection of phosphatidylserine expression on early apoptotic cells using fluorescein labelled annexin V. J. Immunol. Methods 1995, 184, 39-51. [CrossRef]

56. Casciola-Rosen, L.; Rosen, A.; Petri, M.; Schlissel, M. Surface blebs on apoptotic cells are sites of enhanced procoagulant activity: implications for coagulation events and antigenic spread in systemic lupus erythematosus. Proc. Natl. Acad. Sci. USA 1996, 93, 1624-1629. [CrossRef] [PubMed]

57. Deng, X.; Luan, Q.; Chen, W.; Wang, Y.; Wu, M.; Zhang, H.; Jiao, Z. Nanosized zinc oxide particles induce neural stem cell apoptosis. Nanotechnology 2009, 20, 115101. [CrossRef] [PubMed]

58. Xia, M.; Knezevic, D.; Vassilev, L.T. p21 does not protect cancer cells from apoptosis induced by nongenotoxic p53 activation. Oncogene 2011, 30, 346-355. [CrossRef] [PubMed]

59. Taylor, W.R.; Grabovich, A. Targeting the cell cycle to kill cancer cells. In Pharmacology: Principles and Practice; Academic Press: Burlington, MA, USA, 2009; pp. 429-453.

60. Alkhalaf, M.; El-Mowafy, A.M. Overexpression of wild-type p53 gene renders MCF-7 breast cancer cells more sensitive to the antiproliferative effect of progesterone. J. Endocrinol. 2003, 179, 55-62. [CrossRef] [PubMed]

61. Ostrakhovitch, E.A.; Cherian, M.G. Inhibition of extracellular signal regulated kinase (ERK) leads to apoptosis inducing factor (AIF) mediated apoptosis in epithelial breast cancer cells: The lack of effect of ERK in p53 mediated copper induced apoptosis. J. Cell. Biochem. 2005, 95, 1120-1134. [CrossRef] [PubMed]

62. Chaudhary, P.; Sharma, R.; Sharma, A.; Vatsyayan, R.; Yadav, S.; Singhal, S.S.; Rauniyar, N.; Prokai, L.; Awasthi, S.; Awasthi, Y.C. Mechanisms of 4-hydroxy-2-nonenal induced pro-and anti-apoptotic signaling. Biochemistry 2010, 49, 6263-6275. [CrossRef] [PubMed] 
63. Singh, N.; Zaidi, D.; Shyam, H.; Sharma, R.; Balapure, A.K. Polyphenols sensitization potentiates susceptibility of MCF-7 and MDA MB-231 cells to Centchroman. PLoS ONE 2012, 7, e37736. [CrossRef] [PubMed]

64. Mohan, S.; Abdelwahab, S.I.; Kamalidehghan, B.; Syam, S.; May, K.S.; Harmal, N.S.M.; Shafifiyaz, N.; Hadi, A.H.A.; Hashim, N.M.; Rahmani, M. Involvement of NF- $\mathrm{kB}$ and Bcl2/Bax signaling pathways in the apoptosis of MCF7 cells induced by a xanthone compound Pyranocycloartobiloxanthone A. Phytomedicine 2012, 19, 1007-1015. [CrossRef] [PubMed]

65. Ng, W.K.; Yazan, L.S.; Ismail, M. Thymoquinone from Nigella sativa was more potent than cisplatin in eliminating of SiHa cells via apoptosis with down-regulation of Bcl-2 protein. Toxicol. Vitr. 2011, 25, 1392-1398. [CrossRef] [PubMed]

66. Chin, Y.R.; Toker, A. The actin-bundling protein palladin is an Akt1-specific substrate that regulates breast cancer cell migration. Mol. Cell 2010, 38, 333-344. [CrossRef] [PubMed]

67. Gao, F.; Ma, N.; Zhou, H.; Wang, Q.; Zhang, H.; Wang, P.; Hou, H.; Wen, H.; Li, L. Zinc oxide nanoparticles-induced epigenetic change and G2/M arrest are associated with apoptosis in human epidermal keratinocytes. Int. J. Nanomed. 2016, 11, 3859-3874.

(C) 2017 by the authors. Licensee MDPI, Basel, Switzerland. This article is an open access article distributed under the terms and conditions of the Creative Commons Attribution (CC BY) license (http:/ / creativecommons.org/licenses/by/4.0/). 